\title{
Isozyme polymorphism to detect genetic diversity of Jatropha curcas (L.) in India
}

\author{
Rekha R. Warrier, P. Priyadharshini, S. Senthil Vadivu, B. Devika \\ Nagalakshmi, C. Savitha, R. Anandalakshmi, A. Nicodemus, \\ and B. Gurudev Singh
}

Institute of Forest Genetics and Tree Breeding, PB No. 1061, Forest Campus, Coimbatore 641002 India

\begin{abstract}
The Indian Government identified Jatropha curcas L. as the most suitable treeborne oilseed for the production of bio-diesel. The species has spread to many parts of India due to its ability to withstand adverse conditions. Breeding of inter and intra specific Jatrophas for the exploitation of hybrid vigour is one of the most economical means of tree improvement. To study the genetic base of the species distributed in India, 55 accessions of J. curcas from Jammu to Kanyakumari and Jodhpur to Kolkata were assessed using isozyme markers. Fifteen enzyme systems were evaluated for their efficacy in distinguishing the accessions. While three (formate dehydrogenase, malate dehydrogenase and peroxidase) were found useful, twelve did not exhibit any variation and had fixed monomorphic alleles. Each polymorphic enzyme system produced one well resolved polymorphic region except peroxidase which had three. On an average 4 loci $(26.67 \%)$ were found to be polymorphic $(\mathrm{P})$ and mean observed number of alleles per locus (A) was 1.533. Average observed heterozygosity $(\mathrm{Ho})$ was 0.1082 and expected value $(\mathrm{He})$ was 0.0993 with and gene flow $\mathrm{Nm}=0.2177$ showing low level of genetic variation among different accessions suggesting poor segregation of genes over generations. The isozyme variation was measured by standard gene diversity measures using POPGENE v. 1.32. Dendrograms revealed very low heterozygosity leaving little scope for exploitation of hybrid vigour and suggesting that initiating breeding programmes with Indian land races may not lead to substantial genetic gain, vigorous seed set and higher volumes of oil yield.
\end{abstract}

Key words: Jatropha curcas, isozymes, genetic variability, dendrogram, heterozygosity

Correspondence: R. R. Warrier Address: Institute of Forest Genetics and Tree Breeding, PB No. 1061, Forest Campus, Coimbatore 641002 India. E-mail: rekha@icfre.org

DOI: $10.32945 /$ atr3216.2010 


\section{INTRODUCTION}

India, an emerging major player in the global economy, consumes over 127 million tonnes of crude oil a year and imports about $70 \%$ of it thus paying a huge import bill. To tide over this and to overcome the oil crisis in the future, the Planning Commission of India has initiated a National Mission on Biodiesel to identify suitable tree-borne oil seeds, amongst which Jatropha curcas has been recognised as a potential petrocrop.

The pantropic oil-bearing tree Jatropha curcas L. is receiving a lot of attention from policy makers and project developers as it is well adapted to arid and semi-arid climates, and is also known to reclaim wasteland simultaneously, produce bio-diesel and enhance socio-economic development in degraded areas (Achten et al., 2007). Although this species can withstand a wide range of adverse climatic and edaphic conditions, fruit yield declines substantially with reduced rainfall. Several studies are being conducted on the planting material of Jatropha, agro-technologies, properties of the oil and the bio-diesel produced and the fuel efficiency in different types of engines.

Under the Micro-mission on the Production and Demonstration of Quality Planting Material of Jatropha supported by the Department of Biotechnology (DBT), the Government of India (GoI), research on agronomic practices, selection of elite trees, clonal propagation, and tissue culture is being undertaken (Anon, 2006). The National Oil and Vegetable Oil Development (NOVOD) Board is also promoting work on standardization of propagation, establishment of model plantations, detoxification of seed meal, development of preprocessing \& processing equipments, training, besides tree improvement through agricultural and conventional universities, state forest departments and forest development corporations national institutions, Indian Railways, the single largest consumer of high speed diesel (HSD) and a few state road transport undertakings in the country are making efforts to substitute mix biodiesel with High Speed Diesel (Singh, 2006).

In India 12 species of Jatropha have been listed and J. curcas which is considered as a prolific fruit yielder, is an exotic tree species from Portugal and Central America introduced by Portuguese settlers about 500 years ago (Orwa et al.2009). Although it has spread to many parts of India in a short span of time, the genetic base remained small except those changes in the

phenology, biochemical and genetic constitution forced by site quality and associated factors. 
Success of improvement programmes lies in the identification of genetically divergent material and development of genetically superior stocks. Breeding of inter and intra specific Jatrophas for exploitation of hybrid vigour is one of the most economical means of tree improvement. Elsewhere in the world, systematic germplasm collection and evaluation programme to identify superior material from the existing natural variations, establishment of clonal seed orchards, development of mass multiplication techniques to ensure easy supply of elite planting material, a series of multi-locational trials under different agroclimatic conditions to establish authentic data on yield estimates and economic of production have been taken up on a massive scale (Muys et al., 2007).

In India, the Jatropha promotion programmes currently use the "wild" material available locally (Basha and Sujatha, 2007). Although high yielding varieties and cultivars have been identified, some researchers have expressed skepticism over subjecting the wild cultivars (??) to breeding for exploitation of hybrid vigour due to its alleged narrow genetic base. In this scenario, spending valuable financial resources, time and human endeavor on plant improvement (i.e. collection and evaluation of germplasm, including establishment of clonal and seedling seed orchards, multi-locational trials, vegetative multiplication gardens under different agro-climatic conditions for supply of elite planting material on a massive scale) may not pay rich dividends.

It is of paramount importance to evaluate and maintain genetic variability within stands because plantations consisting of genetically uniform materials are highly vulnerable to major climatic fluctuations and pests (Aradhya and Phillips, 1993). Occurrence of multiple molecular forms, popularly called isozyme (specific proteins) had been used as a tool to estimate diversity (Gepts, 1990) and have proven to be the most efficient and inexpensive method for the study of genetic variation in tree species when compared to other biochemical or molecular techniques, or the use of morphological characteristics (Yeh, 1989). Isoenzymes are considered reliable genetic markers in breeding and genetic studies of plant species, due to consistency in their expression, irrespective of environmental factors (Dhatwalia et al., 2009). Offspring from self and cross-pollinations may be differentiated by using appropriate isozymes as specific markers, due to the fact that the electrophoretic pattern is a reflection of the genotype.

This study assessed the extent of genetic distinctness and gene flow pattern of land races of $J$. curcas, using isozyme markers, in a representative set of 55 
accessions from across to obtain data on the variability present in this species and to provide further information about their genetic relations.

\section{MATERIALS AND METHODS}

\section{Sampling sites}

Isozyme analysis was done in fifty five accessions, selected from various Jatropha growing states of the country (Table 1 and Figure 1). The collections were done to include both jatropha growing and non-growing states. The soil types varied from well irrigated and fertile soils to barren and wastelands. Rainfall ranged from low $(500 \mathrm{~mm})$ to as high as $3000 \mathrm{~mm}$.

\section{Sampling and preparation of extract}

Thirty seedlings per accession were studied. Leaf samples, free of any visible infestations, were collected, brought to the laboratory in ice and stored at $4^{\circ} \mathrm{C}$ for further analysis. About $100 \mathrm{mg}$ of tissue was washed once in deionised water and mashed individually in a pre-chilled mortar in $500 \mu \mathrm{l}$ of $0.1 \mathrm{M}$ Tris- $\mathrm{HCl}$ buffer ( $\mathrm{pH}$ 6.8) containing $10 \%$ glycerol and $0.056 \mathrm{M}$ âmercaptoethanol. The resultant slurry was centrifuged at $12,000 \mathrm{rpm}$. for 20 min. in a refrigerated centrifuge and the supernatant was stored at $-20^{\circ} \mathrm{C}$ before use. (Sadasivam \& Manickam, 1996).

\section{Electrophoresis}

Poly Acrylamide Gel Electrophoresis (PAGE) was carried out at low temperature as per standard procedure (Laemmli, 1970) with appropriate modifications. Vertical discontinuous native PAGE was employed using BIORAD electrophoresis system using 16 x $18 \mathrm{~cm}$ glass plates with $1.5 \mathrm{~mm}$ thick poly acrylamide gels. Immediately after electrophoresis, the gels were incubated in the substrate solution(s). The zones where the enzymes were located in the gel were visualized by the appearance of bands. Isozyme zones were designated to define the general area on the zymogram within which the bands migrated. The zones were numbered from the slowest to the fastest migration. The zymogram was photographed, the relative position of each 
Table 1 . Geographical location of $J$. curcas accessions used in the diversity analysis study

\begin{tabular}{|c|c|c|c|c|}
\hline Sl. No. & Accession No. & Latitude Longitude & Location & States \\
\hline 1 & 52 & $08^{\circ} 10^{\prime} \mathrm{N} 77^{\circ} 26^{\prime} \mathrm{E}$ & Kanyakumari & Tamil Nadu \\
\hline 2 & 51 & $08^{\circ} 57^{\prime} \mathrm{N} 77^{\circ} 19^{\prime} \mathrm{E}$ & Coutrallam & Tamil Nadu \\
\hline 3 & 53 & $10^{\circ} 22^{\prime} \mathrm{N} 78^{\circ} 40^{\prime} \mathrm{E}$ & Pudukkotai & Tamil Nadu \\
\hline 4 & 12 & $10^{\circ} 30^{\prime} \mathrm{N} 76^{\circ} 12^{\prime} \mathrm{E}$ & Thrissur & Kerala \\
\hline 5 & 7 & $11^{\circ} 00^{\prime} \mathrm{N} 76^{\circ} 36^{\prime} \mathrm{E}$ & Attapady & Kerala \\
\hline 6 & 42 & $11^{\circ} 01^{\prime} \mathrm{N} 76^{\circ} 57^{\prime} \mathrm{E}$ & Coimbatore & Tamil Nadu \\
\hline 7 & 32 & $11^{\circ} 14^{\prime} \mathrm{N} 77^{\circ} 06^{\prime} \mathrm{E}$ & Annur & Tamil Nadu \\
\hline 8 & 9 & $11^{\circ} 16^{\prime} \mathrm{N} 76^{\circ} 13^{\prime} \mathrm{E}$ & Nilambur & Kerala \\
\hline 9 & 44 & $11^{\circ} 39^{\prime} \mathrm{N} 78^{\circ} 09^{\prime} \mathrm{E}$ & Salem & Tamil Nadu \\
\hline 10 & 17 & $12^{\circ} 31^{\prime} \mathrm{N} 76^{\circ} 53^{\prime} \mathrm{E}$ & Mandya & Karnataka \\
\hline 11 & 13 & $12^{\circ} 59^{\prime} \mathrm{N} 77^{\circ} 33^{\prime} \mathrm{E}$ & Bangalore & Karnataka \\
\hline 12 & 16 & $13^{\circ} 08^{\prime} \mathrm{N} 78^{\circ} 08^{\prime} \mathrm{E}$ & Kolar & Karnataka \\
\hline 13 & 55 & $14^{\circ} 26^{\prime} \mathrm{N} 79^{\circ} 59^{\prime} \mathrm{E}$ & Nellore & Andhra Pradesh \\
\hline 14 & 14 & $14^{\circ} 48^{\prime} \mathrm{N} 74^{\circ} 08^{\prime} \mathrm{E}$ & Uttara Kannada & Karnataka \\
\hline 15 & 15 & $15^{\circ} 08^{\prime} \mathrm{N} 76^{\circ} 55^{\prime} \mathrm{E}$ & Bellary & Karnataka \\
\hline 16 & 54 & $17^{\circ} 25^{\prime} \mathrm{N} 78^{\circ} 25^{\prime} \mathrm{E}$ & Hyderabad & Andhra Pradesh \\
\hline 17 & 19 & $18^{\circ} 23^{\prime} \mathrm{N} 75^{\circ} 34^{\prime} \mathrm{E}$ & Latur & Maharashtra \\
\hline 18 & 18 & $18^{\circ} 33^{\prime} \mathrm{N} 75^{\circ} 00^{\prime} \mathrm{E}$ & Karjat & Maharashtra \\
\hline 19 & 27 & $19^{\circ} 18^{\prime} \mathrm{N} 84^{\circ} 48^{\prime} \mathrm{E}$ & Behrampur & Orissa \\
\hline 20 & 28 & $19^{\circ} 21^{\prime} \mathrm{N} 84^{\circ} 59^{\prime} \mathrm{E}$ & Ganjam & Orissa \\
\hline 21 & 26 & $19^{\circ} 38^{\prime} \mathrm{N} 74^{\circ} 42^{\prime} \mathrm{E}$ & Rahuri & Maharashtra \\
\hline 22 & 30 & $20^{\circ} 18^{\prime} \mathrm{N} 84^{\circ} 49^{\prime} \mathrm{E}$ & Bhubaneshwar & Orissa \\
\hline 23 & 29 & $20^{\circ} 21^{\prime} \mathrm{N} 85^{\circ} 46^{\prime} \mathrm{E}$ & Chandaka & Orissa \\
\hline 24 & 22 & $20^{\circ} 42^{\prime} \mathrm{N} 76^{\circ} 59^{\prime} \mathrm{E}$ & Akola & Maharashtra \\
\hline 25 & 40 & $20^{\circ} 57^{\prime} \mathrm{N} 72^{\circ} 55^{\prime} \mathrm{E}$ & Navsari & Gujarat \\
\hline 26 & 33 & $21^{\circ} 29^{\prime} \mathrm{N} 85^{\circ} 50^{\prime} \mathrm{E}$ & Balasore & Orissa \\
\hline 27 & 11 & $22^{\circ} 04^{\prime} \mathrm{N} 82^{\circ} 08^{\prime} \mathrm{E}$ & Raipur & Chhattisgarh \\
\hline 28 & 1 & $22^{\circ} 05^{\prime} \mathrm{N} 82^{\circ} 09^{\prime} \mathrm{E}$ & Bilaspur & Chhattisgarh \\
\hline 29 & 20 & $22^{\circ} 21^{\prime} \mathrm{N} 75^{\circ} 26^{\prime} \mathrm{E}$ & Mandu & Madhya Pradesh \\
\hline 30 & 24 & $22^{\circ} 35^{\prime} \mathrm{N} 80^{\circ} 22^{\prime} \mathrm{E}$ & Mandla & Madhya Pradesh \\
\hline
\end{tabular}


Table 1. Continued...

\begin{tabular}{|c|c|c|c|c|}
\hline Sl. No. & Accession No. & Latitude Longitude & Location & States \\
\hline 31 & 38 & $22^{\circ} 51^{\prime} \mathrm{N} 88^{\circ} 26^{\prime} \mathrm{E}$ & Kolkatta & West Bengal \\
\hline 32 & 3 & $23^{\circ} 02^{\prime} \mathrm{N} 72^{\circ} 35^{\prime} \mathrm{E}$ & Ambaji & Gujarat \\
\hline 33 & 23 & $23^{\circ} 09^{\prime} \mathrm{N} 79^{\circ} 54^{\prime} \mathrm{E}$ & Jabalpur & Madhya Pradesh \\
\hline 34 & 21 & $23^{\circ} 18^{\prime} \mathrm{N} 75^{\circ} 04^{\prime} \mathrm{E}$ & Ratlam & Madhya Pradesh \\
\hline 35 & 41 & $23^{\circ} 19^{\prime} \mathrm{N} 77^{\circ} 47^{\prime} \mathrm{E}$ & Raisen & Madhya Pradesh \\
\hline 36 & 36 & $23^{\circ} 21^{\prime} \mathrm{N} 85^{\circ} 20^{\prime} \mathrm{E}$ & Ranchi & Jharkhand \\
\hline 37 & 41 & $23^{\circ} 31^{\prime} \mathrm{N} 73^{\circ} 48^{\prime} \mathrm{E}$ & Vidisha & Madhya Pradesh \\
\hline 38 & 4 & $23^{\circ} 32^{\prime} \mathrm{N} 70^{\circ} 52^{\prime} \mathrm{E}$ & Bhavnagar & Gujarat \\
\hline 39 & 56 & $23^{\circ} 32^{\prime} \mathrm{N} 74^{\circ} 26^{\prime} \mathrm{E}$ & Banswara & Rajasthan \\
\hline 40 & 37 & $24^{\circ} 34^{\prime} \mathrm{N} 73^{\circ} 41^{\prime} \mathrm{E}$ & Udaipur & Rajasthan \\
\hline 41 & 39 & $25^{\circ} 03^{\prime} \mathrm{N} 73^{\circ} 53^{\prime} \mathrm{E}$ & Rajsamand & Rajasthan \\
\hline 42 & 35 & $25^{\circ} 51^{\prime} \mathrm{N} 85^{\circ} 46^{\prime} \mathrm{E}$ & Samastipur & Bihar \\
\hline 43 & 34 & $26^{\circ} 16^{\prime} \mathrm{N} 73^{\circ} 01^{\prime} \mathrm{E}$ & Jodhpur & Rajasthan \\
\hline 44 & 49 & $26^{\circ} 26^{\prime} \mathrm{N} 80^{\circ} 19^{\prime} \mathrm{E}$ & Kanpur & Uttar Pradesh \\
\hline 45 & 8 & $26^{\circ} 36^{\prime} \mathrm{N} 75^{\circ} 26^{\prime} \mathrm{E}$ & Churu & Rajasthan \\
\hline 46 & 50 & $26^{\circ} 41^{\prime} \mathrm{N} 78^{\circ} 25^{\prime} \mathrm{E}$ & Lalitpur & Uttar Pradesh \\
\hline 47 & 48 & $26^{\circ} 51^{\prime} \mathrm{N} 80^{\circ} 55^{\prime} \mathrm{E}$ & Lucknow & Uttar Pradesh \\
\hline 48 & 10 & $28^{\circ} 12^{\prime} \mathrm{N} 76^{\circ} 37^{\prime} \mathrm{E}$ & Rewari & Haryana \\
\hline 49 & 47 & $29^{\circ} 02^{\prime} \mathrm{N} 79^{\circ} 31^{\prime} \mathrm{E}$ & Pantnagar & Uttar Pradesh \\
\hline 50 & 45 & $30^{\circ} 07^{\prime} \mathrm{N} 78^{\circ} 19^{\prime} \mathrm{E}$ & Byaasi & Uttranchal \\
\hline 51 & 43 & $30^{\circ} 20^{\prime} \mathrm{N} 77^{\circ} 59^{\prime} \mathrm{E}$ & Dehradun & Uttranchal \\
\hline 52 & 46 & $30^{\circ} 46^{\prime} \mathrm{N} 77^{\circ} 98^{\prime} \mathrm{E}$ & Dudhli & Uttranchal \\
\hline 53 & 5 & $32^{\circ} 06^{\prime} \mathrm{N} 76^{\circ} 32^{\prime} \mathrm{E}$ & Palampur & Himachal Pradesh \\
\hline 54 & 6 & $32^{\circ} 06^{\prime} \mathrm{N} 78^{\circ} 23^{\prime} \mathrm{E}$ & Sangla & Himachal Pradesh \\
\hline 55 & 25 & $33^{\circ} 22^{\prime} \mathrm{N} 74^{\circ} 18^{\prime} \mathrm{E}$ & Rajauri & Jammu \& Kashmir \\
\hline
\end{tabular}




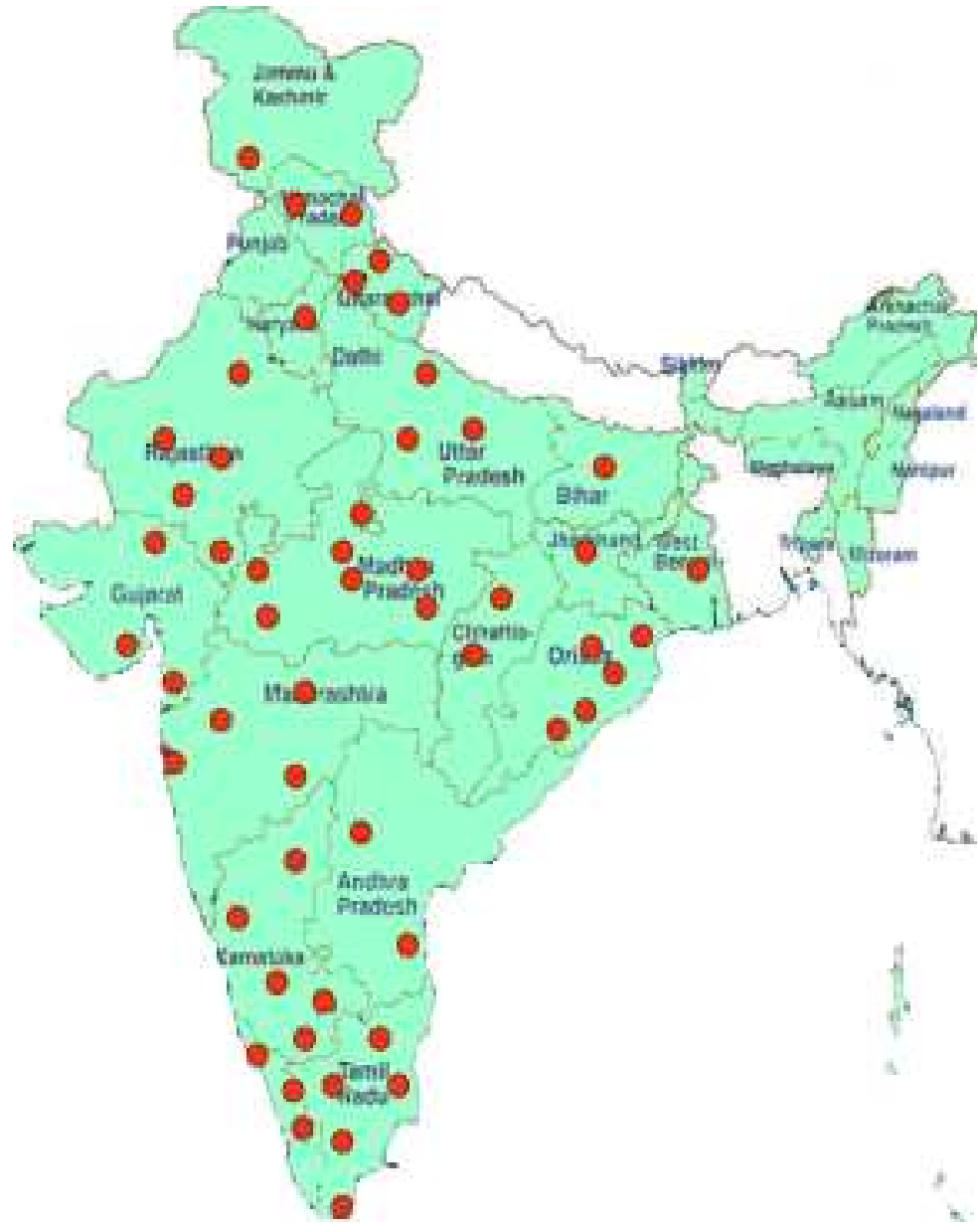

Fig. 1 Map of India showing location of J. curcas accessions used in diversity analysis 
Table 2. Details of enzymes and their enzyme commission (EC) numbers

\begin{tabular}{llll}
\hline S. No. & Enzyme & Commission No. & Class \\
\hline 1. & AAT & EC 2.6.1.1 & Transferase \\
2. & ADH & EC 1.1.1.1 & Oxidoreductase \\
3. & ALD & EC 2.2.1.2 & Transferase \\
4. & FDH & EC 1.2.1.2 & Oxidoreductase \\
5. & G3PD & EC 1.2.1.12 & Oxidoreductase \\
6. & G6PD & EC 1.1.1.49 & Oxidoreductase \\
7. & GDH & EC 1.2.1.41 & Oxidoreductase \\
8. & ICD & EC 1.1.1.41 & Oxidoreductase \\
9. & LDH & EC 1.1.1.27 & Oxidoreductase \\
10. & MDH & EC 1.1.1.37 & Oxidoreductase \\
11. & POD & EC 1.11.1.7 & Oxidoreductase \\
12. & SKD & EC 1.1.1.25 & Oxidoreductase \\
13. & SOD & EC 1.15.1.1 & Oxidoreductase \\
14. & a-EST & EC 3.1.1.- & Hydrolase \\
15. & a-EST & EC 3.1.1.1 & Hydrolase \\
\hline
\end{tabular}

band drawn schematically and scored. Scoring was made for those bands which were clearly visible. Genetic interpretation of enzyme phenotypes was based on observed differences in zymogram profile after activity staining of the gel. Variation in banding patterns was determined by the migration from the origin towards the anode. (Sadasivam \& Manickam, 1996).

\section{Enzymes studied}

Fifteen enzyme systems were selected for detailed analysis after a preliminary survey namely Aspartate Aminotransferase (AAT), Alcohol Dehydrogenase (ADH), Peroxidase (POD), Iso Citrate Dehydrogenase (ICD), Formate Dehydrogenase (FDH), Shikimate Dehydrogenase (SKD), Malate Dehydrogenase (MDH), Lactate Dehydrogenase (LDH), Glucose 6 Phosphate Dehydrogenase (G6PD), Glyceraldehyde 3 Phosphate Dehydrogenase (G3PD), Aldolase (ALD), Superoxide Dis Mutase (SOD), Alpha Esterase (áEST1), Glutamate Phosphate Dehydrogenase (GDH) and Beta Esterase (âEST1) (Table 2). 


\section{Data analysis}

POPGENE (Version 1.32) computer program (Yeh and Boyle, 1997) for genetic data analysis was used to analyse allelic data. Standard genetic variability measures were computed for all accessions including the percentage of polymorphic loci $(P)$, the mean observed number of alleles per locus (na), the mean effective number of alleles per locus (ne), the mean gene diversity (Shannon's information index) $(I)$ and the average observed $(\mathrm{Ho})$ and expected $(\mathrm{He})$ heterozygosities. Nei's original measures of genetic identity $(i)$ and distance (d) (Nei, 1972) were calculated to estimate the degree of genetic differentiation between accessions. Cluster analysis using the UPGMA (Unweighted Pair Group Method using Arithmetic mean) dendrogram (Sneath and Sokal, 1973) was applied to estimate genetic distance values from Nei's distance estimates.

\section{RESULTS AND DISCUSSION}

\section{Isozyme analysis}

Fifteen enzyme systems provided a total of 18 loci for the 55 accessions of Jatropha curcas. Twenty eight percent (5/18) of the resolved isozyme loci were polymorphic ( 0.99 criterion). Out of these eighteen loci, 13 were invariably present in all the accessions while 5 were present in $9,10,11,44$, 46 accessions. The 13 loci, ADH1, AAT1, POD1, ICD1, SKD1, LDH1, G6PD1, G3PD1, ALD1, SOD1, áEST1, GDH1 and âEST1 were invariant in all the accessions analysed and were monomorphic. Unique alleles (present only in the concerned accession) were however, not detected in any of the accessions. Rare alleles (present in lower frequency in more than one accession) were present at the dimorphic MDH1 and FDH1 loci. It was monomorphic to all other accessions. All the alleles were not equally distributed (Tables $3 \mathrm{~A}$ $\& \mathrm{~B})$. There were maximum variations in POD2, POD3, POD4, FDH1, and MDH1, and minimum in ADH1, AAT1, ICD1, SKD1, LDH1, G6PD1, G3PD1, ALD1, áEST1, GDH1 and âEST1 loci.

The genetic variability measures of the 56 accessions are presented in Table 4. The mean observed number of alleles per locus ranged from 1.22 to 
Table 3 A. Overall allele frequencies at eighteen loci in 55 accessions of Jatropha curcas

\begin{tabular}{llllllllllll} 
Allele & \multicolumn{10}{c}{ Locus } \\
\cline { 2 - 11 } & ADH1 & AAT1 & POD1 & POD2 & POD3 & POD4 & ICD1 & FDH1 & SKD1 & MDH1 & LDH1 \\
\hline A & 1.00 & 1.00 & 0.99 & 0.67 & 0.66 & 0.69 & 1.00 & 0.69 & 1.00 & 0.67 & 1.00 \\
B & - & - & 0.01 & 0.20 & 0.20 & 0.19 & - & 0.19 & - & 0.20 & - \\
C & - & - & - & 0.12 & 0.14 & 0.12 & - & 0.12 & - & 0.12 & - \\
\hline
\end{tabular}

Table 3 B. Overall allele frequencies at eighteen loci in 55 accessions of Jatropha curcas

\begin{tabular}{llllllll}
\hline Allele & \multicolumn{7}{c}{ Locus } \\
\cline { 2 - 8 } & G6PD1 & G3PD1 & ALD1 & SOD1 & EST1 & GDH1 & EST1 \\
\hline A & 1.00 & 1.00 & 1.00 & 0.993 & 1.00 & 1.00 & 1.00 \\
B & - & - & - & 0.003 & - & - & - \\
C & - & - & - & 0.003 & - & - & - \\
\hline
\end{tabular}


Table 4. Descriptive statistics (over all loci) of 55 accessions of Jatropha curcas: observed heterozygosity (Ho), expected heterozygosity (He), percent polymorphic loci (P), average number of alleles per locus (na, $99 \%$ criterion), mean effective number of alleles (ne) and Shannon's Information index (I).

\begin{tabular}{|c|c|c|c|c|c|c|}
\hline Acc. No. & $\mathrm{P}$ & Ho & $\mathrm{He}$ & na & ne & I \\
\hline 1. & 22.22 & 0.18 & 0.15 & 1.44 & 1.35 & 0.23 \\
\hline 2. & 22.22 & 0.16 & 0.13 & 1.39 & 1.28 & 0.22 \\
\hline 3. & 16.67 & 0.12 & 0.11 & 1.33 & 1.25 & 0.19 \\
\hline 4. & 22.22 & 0.18 & 0.16 & 1.44 & 1.38 & 0.17 \\
\hline 5. & 22.22 & 0.16 & 0.15 & 1.44 & 1.33 & 0.23 \\
\hline 6. & 22.22 & 0.21 & 0.16 & 1.44 & 1.38 & 0.22 \\
\hline 7. & 22.22 & 0.19 & 0.15 & 1.44 & 1.33 & 0.23 \\
\hline 8. & 27.78 & 0.22 & 0.19 & 1.56 & 1.43 & 0.22 \\
\hline 9. & 27.78 & 0.23 & 0.18 & 1.56 & 1.39 & 0.28 \\
\hline 10. & 27.78 & 0.26 & 0.19 & 1.56 & 1.45 & 0.27 \\
\hline 11. & 22.22 & 0.16 & 0.13 & 1.44 & 1.28 & 0.29 \\
\hline 12. & 16.67 & 0.11 & 0.11 & 1.33 & 1.25 & 0.20 \\
\hline 13. & 16.67 & 0.10 & 0.08 & 1.28 & 1.17 & 0.16 \\
\hline 14. & 11.11 & 0.11 & 0.08 & 1.22 & 1.18 & 0.13 \\
\hline 15. & 11.11 & 0.09 & 0.07 & 1.22 & 1.13 & 0.11 \\
\hline 16. & 11.11 & 0.11 & 0.08 & 1.22 & 1.18 & 0.10 \\
\hline 17. & 22.22 & 0.19 & 0.14 & 1.44 & 1.31 & 0.11 \\
\hline 18. & 22.22 & 0.21 & 0.15 & 1.44 & 1.35 & 0.21 \\
\hline 19. & 22.22 & 0.17 & 0.15 & 1.44 & 1.33 & 0.22 \\
\hline 20. & 22.22 & 0.19 & 0.15 & 1.44 & 1.33 & 0.22 \\
\hline 21. & 22.22 & 0.16 & 0.13 & 1.39 & 1.28 & 0.22 \\
\hline 22. & 16.67 & 0.13 & 0.11 & 1.33 & 1.25 & 0.19 \\
\hline 23. & 16.67 & 0.11 & 0.11 & 1.33 & 1.25 & 0.17 \\
\hline 24. & 16.67 & 0.14 & 0.11 & 1.33 & 1.25 & 0.16 \\
\hline 25. & 16.67 & 0.12 & 0.11 & 1.33 & 1.26 & 0.17 \\
\hline 26. & 16.67 & 0.16 & 0.11 & 1.33 & 1.26 & 0.22 \\
\hline 27. & 22.22 & 0.20 & 0.15 & 1.44 & 1.34 & 0.14 \\
\hline 28. & 16.67 & 0.11 & 0.09 & 1.33 & 1.16 & 0.11 \\
\hline 29. & 11.11 & 0.10 & 0.07 & 1.22 & 1.16 & 0.15 \\
\hline 30. & 11.11 & 0.10 & 0.07 & 1.22 & 1.16 & 0.16 \\
\hline
\end{tabular}


Table 4. Continued...

\begin{tabular}{|c|c|c|c|c|c|c|}
\hline Acc. No. & $\mathrm{P}$ & Ho & $\mathrm{He}$ & na & ne & I \\
\hline 31. & 16.67 & 0.13 & 0.10 & 1.33 & 1.20 & 0.16 \\
\hline 32. & 16.67 & 0.14 & 0.11 & 1.33 & 1.23 & 0.20 \\
\hline 33. & 16.67 & 0.16 & 0.11 & 1.33 & 1.25 & 0.22 \\
\hline 34. & 22.22 & 0.18 & 0.13 & 1.44 & 1.27 & 0.21 \\
\hline 35. & 22.22 & 0.20 & 0.14 & 1.44 & 1.32 & 0.22 \\
\hline 36. & 22.22 & 0.19 & 0.14 & 1.44 & 1.31 & 0.16 \\
\hline 37. & 22.22 & 0.20 & 0.15 & 1.44 & 1.34 & 0.13 \\
\hline 38. & 16.67 & 0.12 & 0.11 & 1.33 & 1.23 & 0.11 \\
\hline 39. & 16.67 & 0.08 & 0.09 & 1.28 & 1.19 & 0.17 \\
\hline 40. & 11.11 & 0.09 & 0.07 & 1.22 & 1.16 & 0.16 \\
\hline 41. & 16.67 & 0.14 & 0.11 & 1.33 & 1.25 & 0.17 \\
\hline 42. & 16.67 & 0.14 & 0.11 & 1.33 & 1.24 & 0.24 \\
\hline 43. & 16.67 & 0.13 & 0.12 & 1.33 & 1.29 & 0.27 \\
\hline 44. & 27.78 & 0.21 & 0.16 & 1.50 & 1.34 & 0.23 \\
\hline 45. & 27.78 & 0.23 & 0.18 & 1.56 & 1.41 & 0.22 \\
\hline 46. & 22.22 & 0.19 & 0.15 & 1.44 & 1.37 & 0.19 \\
\hline 47. & 22.22 & 0.20 & 0.15 & 1.44 & 1.35 & 0.13 \\
\hline 48. & 22.22 & 0.16 & 0.12 & 1.44 & 1.23 & 0.17 \\
\hline 49. & 16.67 & 0.09 & 0.08 & 1.28 & 1.18 & 0.16 \\
\hline 50. & 22.22 & 0.12 & 0.11 & 1.39 & 1.22 & 0.12 \\
\hline 51. & 22.22 & 0.11 & 0.11 & 1.39 & 1.20 & 0.13 \\
\hline 52. & 11.11 & 0.11 & 0.08 & 1.22 & 1.19 & 0.17 \\
\hline 53. & 16.67 & 0.09 & 0.09 & 1.28 & 1.19 & 0.15 \\
\hline 54. & 16.67 & 0.16 & 0.11 & 1.33 & 1.25 & 0.19 \\
\hline 55. & 16.67 & 0.13 & 0.10 & 1.33 & 1.20 & 0.05 \\
\hline Mean & 26.67 & 0.10 & 0.10 & 1.53 & 1.27 & 0.19 \\
\hline SD & 4.57 & 0.04 & 0.03 & 0.09 & 0.08 & 0.05 \\
\hline
\end{tabular}


1.56 (mean 1.53 \pm 0.09 ), while the mean effective number of alleles per locus ranged from 1.2 to 1.45 (mean $1.27 \pm 0.08$ ). The percentage of polymorphic loci $(P)$ (0.99 criterion) varied from 11.11 to 27.78 (mean $26.67 \pm 4.57$ ), the mean observed heterozygosity $(\mathrm{Ho})$ from 0.08 to 0.26 (mean $0.1082 \pm 0.04$ ), the mean expected heterozygosity $(\mathrm{He})$ from 0.08 to 0.19 (mean $0.0993 \pm 0.03$ ) and gene diversity $(I)$ from 0.05 to 0.29 (mean $0.19 \pm 0.05$ ).

Accessions 9, 10, 11, 45, and 46 revealed the maximum (27.78) percentage of polymorphic loci while the least was recorded in accessions 15 , 16, 17, 30, 31, 41 and 53. Accessions 9, 10, 11 and 46 showed the maximum average number of alleles per locus (1.56). The minimum numbers of alleles were, however, recorded in accessions 15, 16, 17, 30, 31, 41 and 53 showing a value of 1.22. The mean value over the accessions was 1.53 . Accession 11 produced the maximum number of heterozygotes (about 26\%) while accession 40 gave the minimum number. The Accession 11 was closely followed by the Accessions 10 and 46 (0.23).

Heterozygosity is directly applied as a measure of genetic variation (Crow, 1986). High levels of heterozygosity are important for survival over long life span of trees (Gregorius and Ziehe, 1986), which is related with the low mortality of seedlings and plants (Mejnartowicz and Lewandowski, 1994). Tree species in general are highly outcrossing and highly heterozygous as compared to herbaceous perennials and annuals, the average level of heterozygosity being twice that of the herbaceous plants (Hamrick et al., 1979).

It was observed that all the accessions had polymorphic loci ranging between 11.11 and 27.78 suggesting that there has been very poor chance for incorporation of new genes into the next generation. It may be noted that Jatropha is an entomophillous species and hence a high level of outcrossing is expected. However, only few populations showed maximum $(27.78 \%)$ polymorphic loci which suggest that large amounts of inbreeding exists within the accessions. The low heterozygosity could be ascribed to a common descent of the population. As the introduction of Jatrophas to the country is ambiguous, the results point to confirmation of a narrow genetic base as indicated by lower proportion of polymorphic loci. With increase in polymorphic loci, the expected heterozygosity and the average heterozygosity would simultaneously increase which is reflected in variation in the heterozygote levels increasing from 0.08 to 0.26 . 
Studies have been reported on isozyme variation in Santalum album (Manojkumar et al, 1998), Acacia (Wickneswari, 1989), Tectona grandis (Kumaravelu, 1979), Eucalyptus (Aradhya and Phillips, 1993; Martins-Corder and Lopes, 1997; Balaji, 1997) and Azadirachta indica (Philomina, 2000).

Reduced number of fertile unrelated trees and a low population size would also result in decreased diversity (Kang and Lindgren, 1998). In the present study, isozyme analyses have provided information about the relative amounts of genetic variation present within Jatropha accessions distributed throughout the country. The genetic variability observed was lower than other plant species summarized by Hamrick et al. (1992). Hence, for improvement of this species, seeds from a wide genetic base need to be obtained to enable its subjection to various ecological conditions. The mean number of alleles per locus per population was 1.53 , which was higher than the average of 1.44 in dicots. The mean expected heterozygosity per population $(0.10)$ in this study was lower than the averages of both angiosperm (0.143), outcrossing windpollinated woody plants $(0.154)$ and 17 tropical tree species $(0.217)$ reported by various authors (Moran, 1992; House and Bell, 1994; Ibrahim, 1996; Martins-Corder and Lopes, 1997).

Although many woody species maintain relatively high levels of genetic variability (Hamrick \& Godt, 1996), some examples exist of widespread conifers with limited genetic variation, such as Pinus resinosa (Fowler \& Morris, 1977) and Tsuga canadensis (Zabinski, 1992), with 0 and $10 \%$ polymorphism, respectively. The most common explanation for the reduction or absence of isozyme variation is that each species has gone through one or more population bottlenecks. The reduced polymorphism and partial inbreeding measured in accessions of Jatrophas, may be due to reduced gene flow. Though geographical range has been considered a good predictor of the levels of genetic variation in plant populations (Hamrick \& Godt, 1989), the present study revealed otherwise. Other studies using isozymes have yielded similar results in trees, the rare Pacific yew (Taxus brevifolia) which occurs over a wide range, indicated low polymorphism $(<50 \%)$ (Scher, 1996).

\section{Genetic diversity}

An enormous amount of protein diversity is characteristic of natural populations (Mallet, 1996). Their genetic structure is mainly influenced by the 
combined effects of random genetic drift, restricted gene flow and differential selection pressures. These effects lead to low within and comparatively high among population genetic variation in species consisting of small and isolated populations (Holderegger and Schneller, 1994; Nevo, 1983). Generally, when populations are close together, having possibility of enough gene exchange, there should be few differences in gene frequency, but if they are far apart, there should be strong differences (Mallet, 1996). This was in contrast to the results obtained in Jatropha where the plant populations have been spread all over the country as hedges. In our study, the genetic identity and distance values calculated between 55 accessions represented as an UPGMA dendrogram (Figure 2) was a fair representation of the Nei's genetic distances between the accessions, which showed many clusters. Analysis of genetic relationships revealed heterogeneous values for Nei's genetic identity $(i)$. It ranged from 0.01 (minimum value) to 0.20 (maximum value). All the 55 accessions clustered at various levels irrespective of the geographical similarity or distance. Most of the accessions showed similarity.

None of the accessions studied were collected from the same localities. Despite this, the genetic variability estimates were very low which might be due to the reduced gene flow between these populations. The 55 accessions have been brought from different places where they have grown in varied climatic and edaphic conditions. The dendrogram clearly depicted narrow genetic diversity among various accessions. Though the different accessions brought from different parts of the country clustered, the genetic distances were very low. Accessions 12-17 from Kerala and Karnataka were clustered together while most accessions from Maharashtra and Madhya Pradesh were grouped together; Accessions 3-11 from the states of Karnataka, Madhya Pradesh, Gujarat, Himachal Pradesh also grouped together. This helped us to arrive at the conclusion of a lack of alliance between genetic data and geographical characteristics of the populations. 


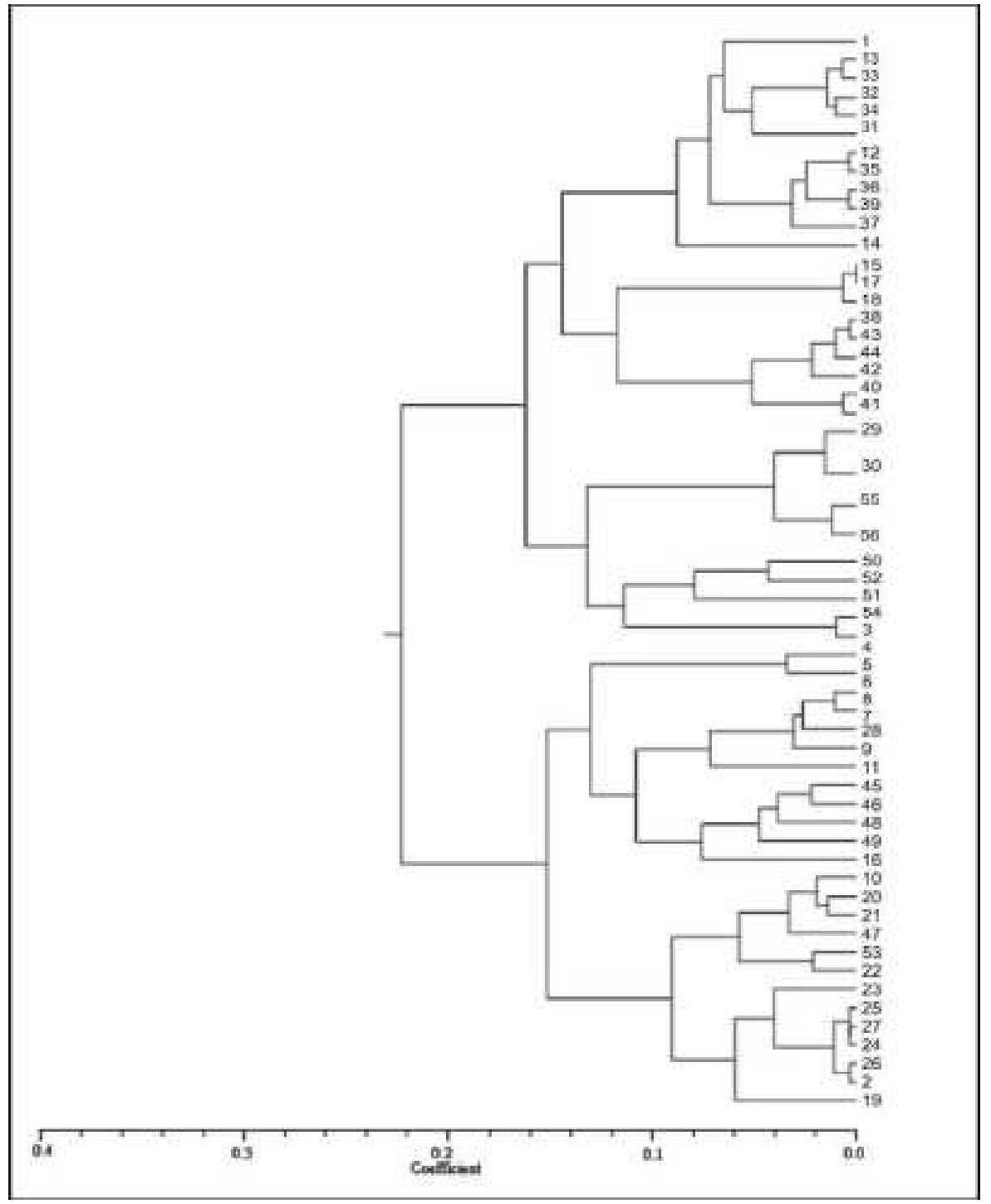

Fig. 2. Dendrogram (UPGMA) representing genetic relationships among 55 accessions of $J$. curcas based on genetic similarity matrix obtained using the allelic profile of isozymes 


\section{CONCLUSION}

The 55 Indian Jatropha accessions did not possess genetic distinctness and failed to be discriminated indicating a narrow genetic base of the material investigated. Further, the intra-population variation as determined by isozyme studies was on par with the genetic variation detected between populations or land races. Such low genetic variation in an allogamous species like J. curcas could be due to the few introductions that have spread across the country primarily, through vegetative propagation. The species has not been improved for productivity and most of the projects that relied on naturally occurring unadapted populations are a result of the few initial introductions. Hence, there is an immediate need for the widening the genetic base of $J$. curcas through import of selected superior germplasm.

Since the country wants to embark upon large scale planting of J. curcas it is essential to procure high yielding varieties or cultivars with very high degree of heterozygosity from its naturally occurring regions and initiate breeding programmes for establishing clonal and seedling seed orchards and vegetative multiplication gardens to ensure higher yields for the farmers and to energy sector. The same can also be used for producing large number of hybrids and match them with different agroclimatic zones. In the second generation breeding programmes, the above material can be used for developing site specific germplasm.

\section{ACKNOWLEDGMENT}

We acknowledge Dr. R.L. Srivastava, Director, Arid Forest Research Institute, Jodhpur, Dr. M.G. Rao, Dean, Forestry, Tamil Nadu Agriculture University, Mettupalayam, Dr. A.K. Mandal, Director, Tropical Forest Research Institute, Jabalpur, Dr. N.K. Vijaykumar, Dean, College of Forestry, Kerala Agriculture University, Trichur for providing the Jatropha accessions to carry out the present study. We are also grateful to the Director General, Indian Council of Forestry Research and Education, Dehradun for the direction and support. 


\section{REFERENCES}

ACHTEN, W., E. MATHIJS, L. VERCHOT, V.P. SINGH and B. MUYS. 2007. Bio-diesel from Jatropha: the life-cycle perspective. FACT seminar Jatropha curcas L.: Agronomy and Genetics. 26-28 March 2007, Wageningen, The Netherlands.

ANON, 2006. Annual Report, 2005-06. Department of Biotechnology, Ministry of Science and Technology, New Delhi.

ARADHYA, K.M. and V.D. PHILLIPS. 1993. Genetic variability in elite Eucalyptus provenances and progenies selected for arid environments in Hawaii. Silvae Genetica 45(2) : 145-150.

BALAJI, B. 1997. Multivariate analysis and interspecific hybridization in Eucalyptus species. M.Sc. (For.) thesis, Forest College and Research Institute, TNAU, Coimbatore.

BASHA, S. D. and M. SUJATHA. 2007. Inter and intra-population variability of Jatropha curcas (L.) characterized by RAPD and ISSR markers and development of population-specific SCAR markers. Euphytica 156: 375-386.

CROW, J. F. 1986. Basic concepts in population, quantitative, and evolutionary genetics. W. H. Freeman \& Comp., New York.

DHATWALIA, V.K., O. P. SATI, M. K. TRIPATHI, V. GUPTA, P. K. CHAUHAN. 2009. An electrophoretic analysis of the isozymes of malate dehydrogenase and peroxidase in different varieties of wheat. Indian Journal of Crop Science. 4 (1\&2).

FOWLER D. P. and R.W. MORRIS. 1977. Genetic diversity in red pine: evidence for low genetic heterozygosity. Canadian Journal of Forest Research 7: 343-347.

GEPTS, P. 1990. Genetic diversity of seed storage proteins in plants. In: A. Brown, M. Clegg, A. Kahler and B. Weir (Eds.) Plant Population Genetics, Breeding and Genetics Resources. Sinaver, Sunderland, MA, USA, pp. 64-82.

GREGORIUS, H.R. and M.ZIEHE. 1986. The significance of over- and underdominance for maintenance of genetic polymorphism. II. Overdominance and instability with random mating. J. Theor. Biol. 118: 115-125.

HAMRICK, J. L., M. J. W. GODT, and S. L. SHERMAN-BROYLES. 1992. Factors influencing levels of genetic diversity in woody plant species. New Forests $\mathbf{6}$ : 95-124.

HAMRICK, J. L., Y. B. LINHART and J. B.MITTON. 1979. Relationships between life history characteristics and electrophoretically detected genetic variation in plants. Ann. Rev. Ecol. Syst. 10: 173-200. 
HAMRICK, J.L. and M.J.W. GODT. 1989. Allozyme diversity in plant species. In: A. H. D. Brown, M. T. Clegg, A. L. Kahler and B. S. Weir (Eds.) Plant population genetics, breeding and genetic resources. Sinauer Associates, Sunderland, Massachusetts, pp. 43-63.

HAMRICK, J.L. and M.J.W. GODT. 1996. Effects of life history traits on genetic diversity in plant species. Philos Trans R Soc Lond B. 351:1291-1298.

HOLDEREGGER, R. and J.J. SCHNELLER. 1994. Are small isolated populations of Asplenium septentrionale variable? Biol. J. Linnean Soc. 51:377-385.

HOUSE, A. P. N. and J. C. BELL. 1994. Isozyme variation and mating system in Eucalyptus urophylla S. T. Blake. Silvae Genetica 43(2-3): 167-176.

IBRAHIM, A. M. 1996. Genetic variation in Faidherbia albida- implications for conservation of genetic resources and tree improvement. Univ. Helsinki Tropic. Forest. Rep., 11: 86.

KANG, K.S. and D. LINDGREN. 1998. Fertility variation and its effect on the relatedness of seeds in Pinus densiflora, Pinus thunbergii and Pinus koraiensis clonal seed orchards. Silvae Genetica 47(4): 196-201.

KUMARAVELU, G. 1979. Isozyme characterization of teak clones. Indian Forester 95.

LAEMMLI, U.K. 1970. Electrophoresis. Nature 227: 680.

MALLET, J. 1996. The genetics of biological diversity from variety to species. In: K.J. Gaston (Ed.) Biodiversity- A biology of numbers and differences. Blackwell Science, UK, pp.13-53.

MANOJKUMAR M. REDDY, SUKANYA SUBRAMANIAN and G. KUMARAVELU. 1998. Isozyme studies in clonal bank of sandal (Santalum album L.). In: Advances in Forestry Research in India, Volume XVIII. 267p.

MARTINS-CORDER, M. P. and C. R. LOPES. 1997. Isozyme characterization of Eucalyptus urophylla (S. T. Blake) and E. grandis (Hill ex Maiden) populations in Brazil. Silvae Genetica 46(4): 192-197.

MEJNARTOWICZ, L. and A.LEWANDOWSKI. 1994. Allozyme polymorphism in seeds collected from IUFRO-68 Douglas-fir test-plantation. Silvae Genetica 43: 181186.

MORAN, G. F. 1992. Patterns of genetic diversity in Australian tree species. New Forests, 6:49-66.

MUYS, B., W.ACHTEN, E.MATHIJS, V.P. SINGH and L.VERCHOT. 2007. Bio-diesel production from Jatropha curcas L.: energy balance, global warming potential and land use impact. Book of abstracts of the Third International Conference on Renewable Resources and Biorefineries, 4-6 June, 2007, Ghent, Belgium, 55p. 
NEI, M. 1972. Genetic distance between populations. Amer Nat, 106: 283-292.

NEVO, E. 1983. In Evolution from Molecules to Man. D.S. Bendell (Ed.), Cambridge University press, 287-321.

ORWA, C., MUTUA, A., KINDT, R., JAMNADASS, R. and ANTHONY, S. 2009 Agroforestree Database: a tree reference and selection guide. Version 4.0 (http:/ /www.worldagroforestry.org/ sites/ treedbs/treedatabases.asp)

PHILOMINA, D. 2000. Genetic analysis of one-parent families for variability, diversity, stability and propagation techniques in neem (Azadirachta indica A. Juss.) Ph.D. thesis, TNAU, Coimbatore, 246p.

SADASIVAM, S. and A. MANICKAM, 1996. Biochemical Methods. New Age International Limited, New Delhi, India.

SCHER, S. 1996. Genetic structure of natural Taxus populations in western North America. In: T.B., Smith and R.K., Wayne (Eds.) Molecular Genetic Approaches in Conservation, pp. 424-?441. Oxford University Press, New York.

SINGH, M.J. 2006. Biodiesel an Environmentally Friendly Alternate Fuel Experience of Indian Railways. In: Brahma Singh, R. Swaminathan and V. Ponraj. (Eds.) Biodiesel Conference Towards Energy Independence - Focus on Jatropha. Paper presented at the conference held at Rashtrapati Nilayam, Bolaram, Hyderabad on 9-10 June, 2006, pp. 289-290.

SNEATH, P.H.A. and R.R. SOKAL. 1973. Numerical Taxonomy, Freeman, San Francisco.

WICKNESWARI, R. and M. NORWATI. 1993. Genetic diversity of natural populations of Acacia auriculiformis. Aust. J. Bot., 41: 65-77.

YEH, F. C. H. 1989. Isozyme analysis for revealing population structure for use in breeding strategy. In: Breeding Tropical Trees: Population Structure and Genetic Improvement Strategies in Clonal and Seedling Forestry. G. I. Gibson, A. R. Griffin and A. C. Matheson (Eds.) Proc. IUFRO Conference, Pattaya, Thailand, pp. 119-132.

YEH, F.C. and T.J.B. BOYLE. 1997. Population genetic analysis of co-dominant and dominant markers and quantitative traits. Belgian J. Bot. $129: 157$.

ZABINSKI, C. 1992. Isozyme variation in eastern hemlock. Can. J. For. Res. 22:18381842. 